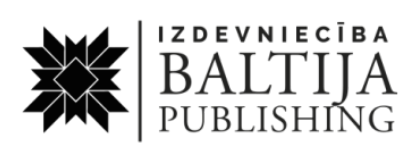

INTERNATIONAL SCIENTIFIC CONFERENCE

\title{
INNOVATION IN SCIENCE: \\ GLOBAL TRENDS AND REGIONAL ASPECT
}

March 12-13, 2021

Proceedings of the Conference

Riga, Latvia

2021 
UDK 0/7(082)

$\operatorname{In} 570$

International Scientific Conference Innovation in Science: Global Trends and Regional Aspect: Conference Proceedings, March 12-13, 2021. Riga, Latvia: «Baltija Publishing». 260 pages.

ISBN: 978-9934-26-050-6

DOI: https://doi.org/10.30525/978-9934-26-050-6

The conference proceedings are focused on the study of innovations in science, taking into account global trends and regional aspects. General issues of the engineering, philological, pedagogical, legal, economic sciences, history of art, agriculture and so on are considered. The publication is designed for scientists, lecturers, postgraduate students, students, as well as for the general readers.

(C) Publishing House "Baltija Publishing”, 2021

(C) Authors of the articles, 2021 
STATE POLICY OF SOCIAL SECURITY

IN THE CONDITIONS OF DECENTRALIZATION OF POWER

Iana Sergeeva

\section{SOCIAL COMMUNICATIONS}

COMMUNICATION IN THE MASS MEDIA AS A PART OF SCIENTISTS' PROFESSIONAL COMMUNICATION Olha Harmatiy 136

\section{PSYCHOLOGICAL SCIENCES}

EUPHEMIZED CONCEPT OF WAR IN ENGLISH MASS-MEDIA DISCOURSE: EVENTS IN THE EAST OF UKRAINE

Olena Bogucharova, Liudmyla Tyshakova 140

EMPIRICAL STUDY OF THE SPIRITUAL POTENTIAL

OF THE PERSONALITY OF A PSYCHOLOGIST

Olena Danilova, Olga Shcherbliuk

FEATURES OF THE DEVELOPMENT

OF ECOLOGICAL SELF-AWARENESS IN ADOLESCENCE

Bogdana Zorya

\section{PEDAGOGICAL SCIENCES}

MEDIATION IN THE CONTEXT

OF MULTILINGUAL EDUCATION IN UKRAINE

Olga Bilozir 149

MEDIA LITERACY IN THE STRUCTURE

OF PROFESSIONAL COMPETENCE OF FUTURE TEACHERS

Halyna Yerko

THE NATIONAL ASPECT OF MUSICAL EDUCATION DEVELOPMENT IN UKRAINE AT THE TURN OF THE $21^{\text {st }}$ CENTURY

Marta Kliuchynska

ORGANIZATION OF DISTANCE LEARNING AT UKRAINIAN

UNIVERSITIES FROM THE POINT OF STUDENTS VIEW

Tetiana Kocharova, Victoria Kutsianova

VOLUNTEER ACTIVITIES IN THE WORK SYSTEM

ON FORMING PROFESSIONAL AWARENESS

OF CORRECTIONAL EDUCATOR

Tetiana Kuznetsova, Maryna Omelchenko 


\section{ORGANIZATION OF DISTANCE LEARNING AT UKRAINIAN UNIVERSITIES FROM THE POINT OF STUDENTS VIEW}

\section{Tetiana Kocharova ${ }^{1}$ Victoria Kutsianova ${ }^{2}$}

DOI: https://doi.org/10.30525/978-9934-26-050-6-46

Even before recent year, a lot of educational institutions of various forms of distance accreditation, which attracted certain consumers of educational services, were known. Namely - conducting classes in the form of online conferences, automated control, correspondence using online programs for sending materials and information.

However, in the conditions of a sudden quarantine, most traditional higher education institutions in Ukraine and other countries also took this path unplanned and forced [1, p. 42].

A survey was conducted among medical students with the usage of google form designed by authors. The questionnaire asked about organization of the distance learning system in emergency situations.

As a result of the conducted survey, the following data were derived. Here was found that many medical institutions use several platforms to conduct classes in a remote format.

The most popular are Zoom - 86.5\%, Moodle - 73.5\% and Google Meet 68.8\%. Next are Classroom - 32.9\%, Teams - 2.4\%, Skype $-1.2 \%$, and regular messengers $-1.2 \%$ (Figure 1 ).

But according to students opinions, Google Meet with a score of $50 \%$ appeared as the most convenient to learn.

Much less was chosen Moodle - 11.2\%, Classroom - 9.4\%, Zoom - 2.4\%, Teams - 2.4\%, Skype - 0.6\%, Discord - 2.4\%, Classroom - 9.4\%, Zoom $2.4 \%$, Teams $-2.4 \%$, Skype $-0.6 \%$, Discord $-2.4 \%$. (Figure 2).

The choice of the most acceptable format of education for medical students was distributed as follows: Distance learning - 35.3\%, Full-time education $-29.4 \%$, Mixed form of education $-34.7 \%$.

For independent mastering of the topic during distance learning students use mainly electronic versions of textbooks $-90 \%$, as well as paper textbooks $-58.8 \%$, articles on the Internet $-63.5 \%$, lectures of the department $-69.4 \%$, public scientific publications $-39,4 \%$.

\footnotetext{
${ }^{1}$ Kharkiv National Medical University, Ukraine

${ }^{2}$ Kharkiv National Medical University, Ukraine
} 


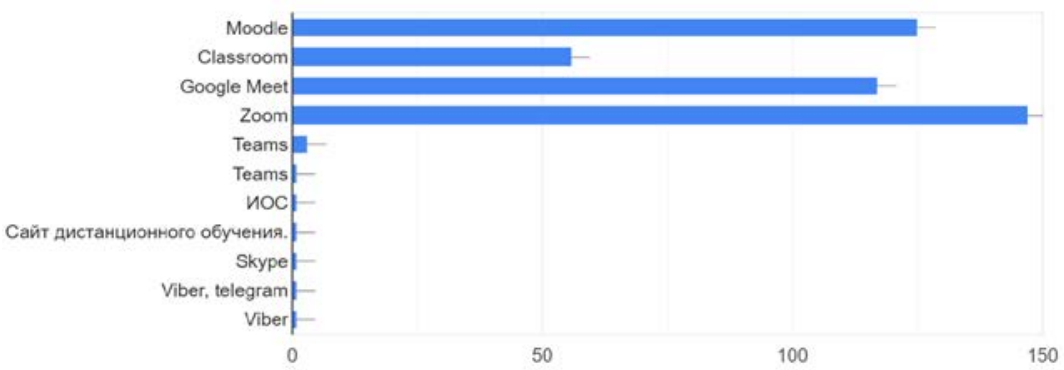

Figure 1. Survey results of used learning platforms
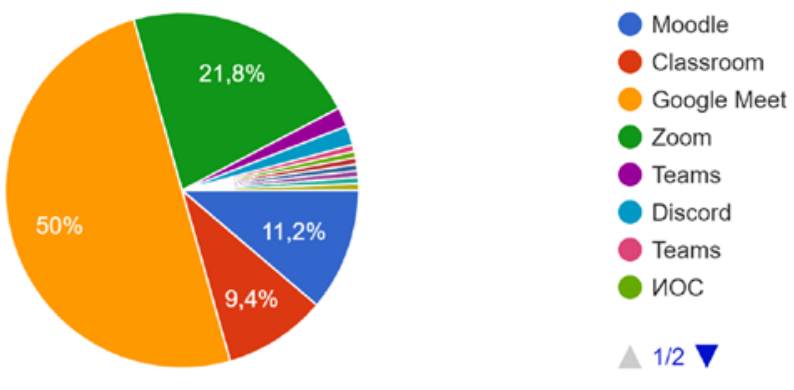

Figure 2. Survey results of preferred learning platforms

It should be noted that the priority of electronic versions of textbooks is not a feature only of the distance form, because they are also used by students during the full-time format of study.

In our opinion, the effectiveness of information perception in the form of distance depends on the psychological characteristics of the student to perceive quickly and efficiently material, technical capabilities of sound, image, and network quality, as well as methods of clear and understandable teaching of material in accordance with the discipline program.

This conclusion is confirmed by the results of the choice of factors that hindered distance learning, namely: Poor sound or image transmission $25.9 \%$, Poor internet connection $-41.8 \%$, Absence of face-to-face contact with the teacher $-37.6 \%$, The problem of perception of information in electronic form - 33.5\%, Nothing interfered - 26.5\%

The lack of face-to-face contact with the teacher also turned out to be a psychological problem for students during the assimilation of new 
information, and makes up a large percentage of the general factors influencing learning.

At the same time, the productivity of medical students was affected by distance learning as follows: In $20 \%$ of percent productivity did not change, $14.1 \%$ could not answer the question in $65.9 \%$ productivity has changed.

Of these, in $62.2 \%$ productivity changed for the better, and in $37.8 \%$ it deteriorated. The decrease in productivity is inferior to the improvement of $62.2 \%$, but still has a large percentage of $37.8 \%$.

The most important problem of distance learning is the lack of practice, especially for senior students. The vast majority, $77.6 \%$ of students, feel lacked practical skills while studying. And only $22.4 \%$ do not feel it.

In general, satisfaction with distance learning is shown by the following results: The quality of education satisfies $61.8 \%$ of students, does not satisfy $29.4 \%$, does not satisfy even in full-time education $8.8 \%$.

Obviously, the relations of participants in distance learning are quite different from the classic interactive model of a modern university teacher student. And as can be seen from the survey, the process of adaptation of students and teachers to distance learning inevitably involved difficulties.

Despite the fact that the productivity of many respondents increased during distance learning, most students did not want to continue distance learning after the end of quarantine. $47.1 \%$ of medical students answered this question Yes, but the majority of $52.9 \%$ denied.

However, there is no doubt that the face-to-face form of the educational process can combine new learning methods with traditional ones.

\section{References:}

1. Кочарова T.P. (2020) Dosvid dystancijnogho vykladannja kursu «Medychna informatyka» studentam dennoji formy v period karantynu [Experience of distance teaching of the course «Medical Informatics» to full-time students during the quarantine period]. Proceedings of the XIII Mizhnarodna naukovo-metodychna internet-konferencija Suchasni koncepciji vykladannja pryrodnychykh dyscyplin $u$ medychnykh osvitnikh zakladakh. Kharkiv: KhNMU, 25.11.2020, pp. 42-44. 